\title{
The Innovation Revolution in Business Models in Indonesian Hybrid Organizations
}

\author{
Bambang Agus Sumantri ${ }^{1}$, Suhardi ${ }^{2}$, Samari $^{3}$ \\ \{bambang.as@unpkediri.ac.id ${ }^{1}$, suhardi@unpkediri.ac.id ${ }^{2}$, samari@unpkediri.ac.id ${ }^{3}$ \} \\ Ph.D Student, Faculty of Economics and Business, Jenderal Soedirman University \\ and Lecturer at the Faculty of Economics and Business, Nusantara University PGRI Kediri, \\ Indonesia ${ }^{1}$, Faculty of Economics and Business, Nusantara University PGRI Kediri, \\ Indonesia ${ }^{2}$ Faculty of Economics and Business, Nusantara University PGRI Kediri, \\ Indonesia ${ }^{3}$.
}

\begin{abstract}
That business model innovation often does not occur because organizations cannot identify business models that are suitable for new technologies or solutions. Innovation revolution in business models in hybrid organizations in Indonesia. This research is a library research in the early stages of deepening hybrid organizations in Indonesia related to the revolution of innovation in a business model. Primary data sources used are research journals, on-line news, and legislation in Indonesia related to this research. It can be concluded that the innovation revolution in the business model of hybrid organizations in Indonesia is as follows: the conclusions of this paper are: Business models continue to be developed that affect innovations of hybrid organization-business models in Indonesia consisting of three organizational patterns, namely: cooperatives, MSMEs, and BUMDesa. The pattern of Indonesian cooperative organizations based on templates was developed from Europe. The pattern of MSME Organizations in Indonesia, in a template, is mirrored in the United States. Explanation of the BUMDesa organizational pattern is the marketisation of the non-profit sector, where non- profit organizations are encouraged to focus on generating commercial revenue from service delivery contracts. The strengths of policies and operational processes in hybrid organizations in Indonesia are as follows: Law Number 25 of 1992 concerning Cooperatives, Law Number 20 of 2008 concerning Micro, Small and Medium Enterprises (MSMEs), and Law Number 06 of 2014 concerning villages.
\end{abstract}

Keywords: business model, innovation, revolution, and hybrid-organization.

\section{Introduction}

Innovations in the Business Model Revolution in Indonesia we specifically focus on hybrid organizations (cooperatives, MSMEs, and BUMDesa) in small and medium categories, not including larger organizations. This focus allows us to draw detailed conclusions for this specific context, even though this is a preliminary study. Thus, specifically answering the question whether hybrid organizations (cooperatives, MSMEs, and BUMDesa) small and medium categories that are more resource limited can benefit from innovation. The small size of the organization analyzed promises that the relationship between innovation and direct business models in general. 
That business model innovation often does not occur because organizations cannot identify business models that are suitable for new technologies or solutions [1].

Build a comprehensive research agenda that aims to develop tools and processes to help organizations bridge the design-implementation gap in sustainable business model innovations [2]. Define sustainable business model innovation as the conceptualization and implementation of sustainable business models. In this case the innovation in question is the business model innovation that is the perspective of the organization in the 1990s until today [3]. The first pattern is Indonesian Cooperatives. Paul Hubert Casselman's definition in his book is titled "The Cooperative Movement and some of its Problems" which says that: "Cooperation is an economic system with social content." Research: Cooperative Innovation Hub (CIH) Lab. FEB UNSOED Cooperatives and SMEs in cooperation with the Kopkun Institute and LPDB-KUKM in October-November 2019 stated that Priority for Cooperative Innovation in Upcoming Indonesia is business model innovation (76.51 percent) [4].

Revolution of Business Models

The business model revolution can be categorized into three concepts, namely:

a) Business Model.

b) Business Model Innovation.

c) Sustainable Business Model Innovations.

Furthermore, the three concepts of the business model revolution can be explained in table 1 below:

Table 1. Business Model

\begin{tabular}{|c|c|}
\hline Generation & Business Model \\
\hline $\begin{array}{l}\text { The most } \\
\text { basic }\end{array}$ & $\begin{array}{l}\text { business model a la shop owner } \\
\text { Explanation: } \\
\text { That is, open a store where potential customers are likely to be, then } \\
\text { display products (goods or services). }\end{array}$ \\
\hline $\begin{array}{l}\text { Introduced in } \\
\text { the early } 20 \text { th } \\
\text { century }\end{array}$ & $\begin{array}{l}\text { Hook and bait business model or Business models of scissors and } \\
\text { razors or Business models of binding products Explanation: } \\
\text { The model works by offering basic products at low price levels, } \\
\text { often in the price of a loss (bait), then charging fees for the refill } \\
\text { product, or other products or services that are bound. Example: } \\
\text { scissors (bait) and a knife (hook); cellphone (bait) and talk credit / } \\
\text { sms / data package (hook); printer (bait) and ink refill or paint } \\
\text { (hook); camera (bait) and printed photos (hook). } \\
\text { Software that provides document reader software for free, but } \\
\text { charges a certain amount for document writing software. }\end{array}$ \\
\hline $1950 \mathrm{~s}$ & $\begin{array}{l}\text { The new business model of McDonald's restaurants and Toyota } \\
\text { companies }\end{array}$ \\
\hline $1960 s$ & The innovators are Wal-Mart and Hypermarkets \\
\hline $1970 \mathrm{~s}$ & New business models from FedEx and Toys R Us \\
\hline $1980 \mathrm{~s}$ & Blockbuster, Home Depot, Intel, dan Dell Computer \\
\hline 1990s & Southewst Airlines, Netflix, eBay, Amazon.com, dan Starbuck \\
\hline $2000 s$ & The era of dot-com companies \\
\hline $2010 \mathrm{~s}$ & $\begin{array}{l}\text { Business models depend on how technology is used, for example } \\
\text { entrepreneurs in cyberspace have also created new models as a } \\
\text { whole that are entirely dependent on existing or developing } \\
\text { technology. By utilizing technology, business people can reach } \\
\text { markets in large numbers (effectively) with minimal costs }\end{array}$ \\
\hline
\end{tabular}




\begin{tabular}{ll}
\hline Generation & Business Model \\
\hline & (efficient). \\
$2020 \mathrm{~s}$ & "Youtube channel" web business model in a pandemic condition \\
& COVID-19 Virus, the concept of "New Normal". \\
\hline
\end{tabular}

Source: (Literature study results, 2020)

Table 2. Types of Business Models

\begin{tabular}{ll}
\hline No & \multicolumn{1}{c}{ Business Model Name } \\
\hline 1 & Business Network (networking) \\
2 & Subscription Business (subscription) \\
4 & Low Cost Business (low cost) \\
5 & Distribution Business (distribution) \\
6 & Business Exclusivity (exclusivity) \\
7 & Seemium business \\
8 & Business Loyalty (loyalty) \\
9 & Collective Business (collective business system) \\
10 & Content Business (online content) \\
11 & Online Auction Business (online auction) \\
12 & Monopoly Business \\
13 & Offline and Online Business (Brick and Clik) \\
14 & Tiered Marketing Business (multi level marketing) \\
15 & Direct Selling Business (direct selling) \\
16 & Advertising business (advertising) \\
17 & Razor Business (freebie marketing) \\
18 & Business Cut Supply Chain (disintermediation) \\
19 & Premium Business \\
20 & Business Pyramid Scheme (pyramid scheme) \\
21 & Open Source Business(open sources) \\
22 & Business Value Added Reseller (VAR) \\
23 & Auction Business (auction) \\
\hline & Adapted from: http://en.wikipedia.org/wiki/Modelbisnis(2020)
\end{tabular}

\section{Literature Review}

\subsection{Organization-Hybrid of Definition}

A description of the development of characteristics, relating to Hybrid-Organization, is in the following table 3 :

Table. 3 Organization-Hybrid

$\begin{array}{cl}\text { Organization-Hybrid } & \text { In particular, non-profit distribution organizations are prohibited } \\ & \text { from legally distributing residual 'income' to those who have } \\ & \text { managerial or ownership interests (5). }\end{array}$




\begin{abstract}
Organization-Hybrid Presents organizational templates for the categories of private, public and non-profit organizations.

Private sector organizations are guided by market forces to maximize financial returns, are owned by shareholders, are regulated according to the size of share ownership, and generate revenue from sales and costs.

Public sector organizations are characterized as being guided by the principles of public benefit and collective choice, owned by citizens and the state, and resources through taxation.

Nonprofit sector organizations pursue social and environmental goals, are owned by members, are governed by the election of personal representatives, are managed by a combination of employees and volunteers and generate income from

Organizationmembership fees, donations, and inheritance (6).

Hybrid Organizational forms that are not aligned with the ideal categorical characteristics underlined are labeled hybrids. By pursuing financial and social aims, Social Enterprise (SE) is a classic example of hybrid organizations because they combine property related to private, public, and non-profit organizations. (7), (8), (9), (10), (11), (12), (13).
\end{abstract}

Organization-Hybrid Conceptualizing social enterprises is an organization that trades, not to get personally, but to produce positive social and environmental externalities (14).

Organization-Hybrid The definition of SE is abundant, and reflects different regional differences (15).

Organization- $\quad$ For example, in the US, SE discourse is dominated by marketHybrid based approaches to generation income and social change. (16), (17), (18).

Organization- $\quad$ Europe, SE lies in the cooperative tradition of collective social Hybrid action (19), (20).

Organization-Hybrid The UK borrows from both traditions, and the proposed definition of the government states that SE is a business with mainly social goals that surplus is mainly reinvested for that purpose in business or in the community, rather than being driven by the need to maximize profits for shareholders and owners (21).

Organization- All of these definitions draw two definitions of SE Hybrid characteristics: adoption of some form of commercial activity to generate income; and pursue social goals. (22), (23), (24), (25).

Organization-Hybrid Thus, SE differs from organizations in the private sector that seek to maximize profits for personal gain by prioritizing social change over personal wealth creation: typical social goals include reducing poverty, inequality, homelessness, carbon emissions and unemployment (11), (26). 


\subsection{Hybrid-Organization Position}

Hybrid organization position among government, business, and social sector, can be explained in the following figure $\mathbf{1}$ :

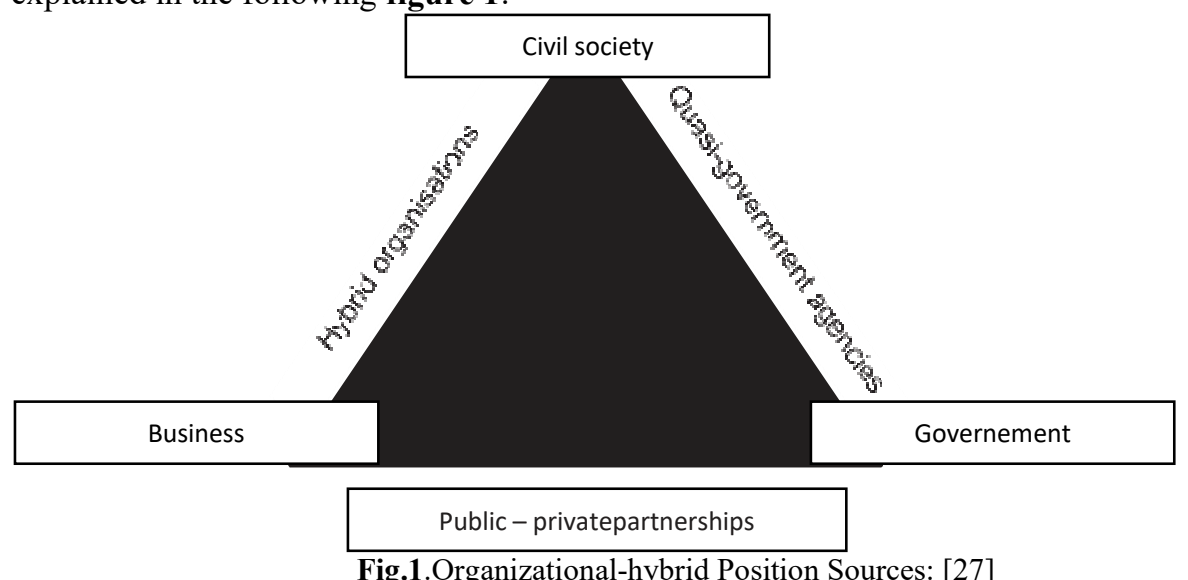

The area of Organizational-Hybrid Strategy, can be explained briefly in Figure 2 below: Social objectives (increasing attention)

Business objectives

\begin{tabular}{|c|c|c|c|c|}
\hline \multirow[b]{2}{*}{$\begin{array}{l}\text { organisasi hybrid } \\
\text { Traditional } \\
\text { charity or } \\
\text { nonprofit } \\
\text { organization }\end{array}$} & \multicolumn{4}{|l|}{ organisasi- } \\
\hline & $\begin{array}{c}\text { social } \\
\text { enterprise }\end{array}$ & $\begin{array}{l}\text { Social venture startup } \\
\text { for social } \\
\text { entrepreneurship }\end{array}$ & $\begin{array}{l}\text { cooperatives and } \\
\text { social businesses }\end{array}$ & $\begin{array}{c}\text { Conventional } \\
\text { commercial } \\
\text { firm }\end{array}$ \\
\hline $\begin{array}{l}\text { Seek grants, sponsorship, } \\
\text { donations, philanthropy etc. }\end{array}$ & $\begin{array}{l}\text { Mixed } \\
\text { income }\end{array}$ & $\begin{array}{l}\text { evenue, commercial } \\
\text { and external funding }\end{array}$ & $\begin{array}{r}\text { Financially self-s } \\
\text { earned in }\end{array}$ & $\begin{array}{l}\text { ficient from } \\
\text { me }\end{array}$ \\
\hline
\end{tabular}

Fig.2. Areas of Organizational-Hybrid Strategy Sources: [27]

Then it can be concluded and patterned as in the following table 4:

Table 4. Perspectives Purpose of Profit and Business-Social Relations

\begin{tabular}{llll}
\hline Perspectives on & $\begin{array}{l}\text { Philanthropy } \\
\text { Organizations }\end{array}$ & Hybrid Organizations & $\begin{array}{l}\text { Business } \\
\text { Organizational }\end{array}$ \\
\hline $\begin{array}{l}\text { Purpose of Profit Search } \\
\text { Business-Social }\end{array}$ & $\begin{array}{l}\text { Minimalist Profit } \\
\text { Social }\end{array}$ & Medium Profit & $\begin{array}{l}\text { Maximum Profit } \\
\text { Re }\end{array}$ \\
lations & & & $\begin{array}{l}\text { Business is full of } \\
\text { Corporate } \\
\text { Patterns }\end{array}$ \\
\hline
\end{tabular}

Source: (analysis results based on literature study, 2020)

\section{Result and Discussion}

In the revolution referred to is the business model innovation (Hybrid-organization) in Indonesia classified in three forms, namely: First 1990s, namely the linkage about 
cooperatives [28]. The second form of the 2000s, namely micro, small and medium enterprises [29]. And the third form of the 2010s, namely concerning Village-Owned Enterprises [30]. Furthermore, the comparative patterns of hybrid organizations in Indonesia (cooperatives, MSMEs, and BUMDesa) can be explained briefly in table 5 below:

Table 5. Comparison of Cooperatives, MSMEs and BUMDesa

\begin{tabular}{|c|c|c|c|}
\hline Perspective & Cooperatives & MSMES & BUMDesa \\
\hline $\begin{array}{l}\text { Relationship } \\
\text { Pattern }\end{array}$ & $\begin{array}{l}\text { Cooperative } \\
\text { management } \\
\text { members }\end{array}$ & individual - family & $\begin{array}{l}\text { Manager of BUMDesa - } \\
\text { village government - } \\
\text { village community }\end{array}$ \\
\hline Basic legislation & $\begin{array}{l}\text { Law Number } 25 \text { of } 1992 \\
\text { concerning Cooperatives }\end{array}$ & $\begin{array}{l}\text { Law Number } 20 \text { Year } \\
2008 \\
\text { concerning MSMEs }\end{array}$ & $\begin{array}{l}\text { Law Number } 06 \text { Year } \\
2014 \quad \text { concerning } \\
\text { Villages }\end{array}$ \\
\hline Function and role & $\begin{array}{l}\text { build and develop the } \\
\text { potential and economic } \\
\text { capacity of members in } \\
\text { particular and society in } \\
\text { general, to improve their } \\
\text { economic and social } \\
\text { welfare; (Chapter } 3 \\
\text { Article } 4 \text { Paragraph a of } \\
\text { Law Number } 25 \text { of } \\
\text { 1992). }\end{array}$ & $\begin{array}{l}\text { its position as a major } \\
\text { player in economic } \\
\text { activity in various } \\
\text { sectors, the largest } \\
\text { provider } \\
\text { employment, } \\
\text { important player in the } \\
\text { development of local } \\
\text { economic activities } \\
\text { and community } \\
\text { empowerment, } \\
\text { creator of new markets } \\
\text { and sources of } \\
\text { innovation, } \\
\text { its contribution in } \\
\text { maintaining the balance } \\
\text { of payments through } \\
\text { community export } \\
\text { activities thereby } \\
\text { reducing poverty and } \\
\text { others. }\end{array}$ & $\begin{array}{l}\text { business development; } \\
\text { and village } \\
\text { development, } \\
\text { empowering village } \\
\text { communities, and } \\
\text { providing assistance to } \\
\text { the poor through grants, } \\
\text { social assistance, and } \\
\text { revolving fund activities } \\
\text { stipulated in the Village } \\
\text { Income and Expenditure } \\
\text { Budget. (article 89, } \\
\text { Law Number } 06 \\
\text { Year 2014) }\end{array}$ \\
\hline $\begin{array}{l}\text { business entity } \\
\text { whose members }\end{array}$ & $\begin{array}{l}\text { individual person or } \\
\text { cooperative legal entity, } \\
\text { based on activities based } \\
\text { on cooperative principles } \\
\text { as well as a people's } \\
\text { economic movement } \\
\text { based on family } \\
\text { principles. }\end{array}$ & $\begin{array}{l}\text { productive business } \\
\text { owned by individuals } \\
\text { and / or individual } \\
\text { business entities. }\end{array}$ & $\begin{array}{l}\text { BUMDesa is a village } \\
\text { business formed / } \\
\text { established by the } \\
\text { village government in } \\
\text { which capital ownership } \\
\text { and management are } \\
\text { carried out by the } \\
\text { village government } \\
\text { and the community }\end{array}$ \\
\hline
\end{tabular}




\begin{tabular}{|c|c|c|c|}
\hline Perspective & Cooperatives & MSMEs & BUMDesa \\
\hline The main purpose & $\begin{array}{l}\text { a cooperative is to } \\
\text { improve the welfare of } \\
\text { members in particular, } \\
\text { and society in general. }\end{array}$ & $\begin{array}{l}\text { Aiming to foster a } \\
\text { business climate in } \\
\text { the business } \\
\text { community which } \\
\text { will create jobs so } \\
\text { as to reduce } \\
\text { unemployment. }\end{array}$ & $\begin{array}{l}\text { the purpose of the } \\
\text { establishment } \\
\text { BUMDesa is the } \\
\text { government's efforts to } \\
\text { improve the financial } \\
\text { capabilities of the } \\
\text { village government in } \\
\text { the administration of } \\
\text { government and } \\
\text { increase community } \\
\text { income through various } \\
\text { economic business } \\
\text { activities of rural } \\
\text { communities. }\end{array}$ \\
\hline $\begin{array}{l}\text { Capital } \\
\text { Resources }\end{array}$ & the members & individual & $\begin{array}{l}\text { Village Fund Allocation } \\
\text { (APBN) and the } \\
\text { community. }\end{array}$ \\
\hline Profit form & $\begin{array}{l}\text { remaining business } \\
\text { results (distributed to } \\
\text { members) }\end{array}$ & $\begin{array}{l}\text { individual business } \\
\text { profits (for owners and } \\
\text { opening up jobs) }\end{array}$ & $\begin{array}{l}\text { BUMDesa benefits } \\
\text { (for social activities } \\
\text { and community } \\
\text { services in the village) }\end{array}$ \\
\hline $\begin{array}{l}\text { Organizational } \\
\text { Pattern }\end{array}$ & $\begin{array}{l}\text { template sources } \\
\text { developed from Europe, } \\
\text { Borzaga and Defourny } \\
(2001)[31] \text {; } \\
\text { Defourny and Nyssens } \\
(2010) \text {; Nyssens (2006) }\end{array}$ & $\begin{array}{l}\text { The pattern of MSMEs } \\
\text { in Indonesia is } \\
\text { template-based in the } \\
\text { United States, where } \\
\text { social enterprise (SE) } \\
\text { discourse is dominated } \\
\text { by market-based } \\
\text { approaches to income } \\
\text { generation and social } \\
\text { change. Austin et al. } \\
(2006) \text {; Dees } \\
\text { (1998)[32]; Defourny } \\
\text { and Nyssens (2010). }\end{array}$ & $\begin{array}{l}\text { BUMDesa in the } \\
\text { organizational pattern } \\
\text { has the pattern } \\
\text { conveyed by Laville } \\
\text { and Nyssens (2001); } \\
\text { Mair and Martì (2006); } \\
\text { Peattie and Morley } \\
\text { (2008); Peredo } \\
\text { and McLean (2006), } \\
\text { which are social } \\
\text { enterprises (SE): } \\
\text { adoption of some form } \\
\text { of commercial activity } \\
\text { to generate income; } \\
\text { and pursue social } \\
\text { goals. }\end{array}$ \\
\hline
\end{tabular}

Source: (Based on various related Law Sources, 2020)

\subsection{Cooperative}

The embryo of Indonesian cooperatives has a long journey, since the Indonesian Cooperative was pioneered by: R. Aria Wiriatmaja (a governor in Purwokerto 1896). But what is analyzed in the context here is organizational behavior in cooperatives after the advent of Law Number 25 of 1992 concerning Cooperatives. Chapter III Article 4 paragraph a of Law Number 25 of 1992: the function and role of cooperatives is to build and develop the potential and economic capacity of members in particular and society in general, to improve their economic and social welfare;

From a temporal perspective, social enterprise (SE) is not a new form of organization, but a product of the evolutionary development of nonprofit or voluntary organizations [33], [34] cooperatives and joint organizations (cooperative). 
Business model innovation:

a) the worker co-op model or the workers' cooperative,

b) co-op startup or cooperative startup,

c) co-op platform or cooperative platform,

d) social co-op or social cooperatives and

e) community co-op or community cooperative.

The pattern of Indonesian cooperative organizations based on templates was developed from Europe [19], [20].

\subsection{Micro, Small and Medium Enterprises (MSMEs)}

The second form of the 2000s, namely micro, small and medium enterprises (Law Number 20 of 2008 concerning MSMEs). Chapter III Article 5 paragraph a of Law Number 20 Year 2008: increasing the role of Micro, Small and Medium Enterprises in regional development, job creation, income distribution, economic growth, and alleviation of people from poverty; and there is also some evidence of 'relabeling' by organizations to define themselves as SE as a broader category in policy and practice [35].

The pattern of MSMEs in Indonesia is template-based in the United States, where social enterprise (SE) discourse is dominated by market-based approaches to income generation and social change. [7], [8], [16].

\subsection{Village-Owned Enterprises (BUMDesa)}

The third form of the 2010s, namely regarding Village-Owned Enterprises (Law Number 6 of 2014 concerning Villages). Chapter I Article 1 paragraph 6 of Law Number 6 Year 2014: Village-Owned Enterprises, hereinafter referred to as BUM Desa, are business entities whose entire or most of their capital is owned by the Village through direct participation from village assets that are separated to manage assets, services, and other businesses for the maximum welfare of the village community. This evolutionary account blurs the line between various forms of organization and the position of social enterprises (SE) at the intersection of the private, public and non-profit sectors [8]. The key factor in this explanation is the marketisation of the non-profit sector, where nonprofits are encouraged to focus on generating commercial revenue from service delivery contracts [36], [37] ( BUMDesa). Minister of Home Affairs Regulation No. 39 of 2010, BUMDesa is a village business formed / established by the village government in which capital ownership and management are carried out by the village government and the community. The purpose of the establishment of BUMDesa is the government's efforts to increase the financial capacity of the village government in administering government and increasing community income through various economic business activities of rural communities. The existence of BUMDesa is also strengthened by Law No. 6 of 2014 discussed in Chapter X articles 87-90, which among others states that the establishment of BUMDesa is agreed through village deliberations and is managed with a family and mutual cooperation spirit.

BUMDesa in the organizational pattern has the pattern conveyed by [22], [23], [24], [25], which are social enterprises (SE): adoption of some form of commercial activity to generate income; and pursue social goals. 


\section{Conclusions}

This research is a library research in the deepening of hybrid organizations related to the revolution of the innovation of a business model.

The conclusions of this paper are:

a) Business models continue to be developed that affect innovation in the hybrid organization-business model in Indonesia consisting of three organizational patterns, namely: cooperatives, MSMEs, and BUMDesa. The pattern of Indonesian cooperative organizations based on templates was developed from Europe. The pattern of MSME Organizations in Indonesia, in a template, is mirrored in the United States. Explanation of the BUMDesa organizational pattern is the marketisation of the non-profit sector, where non-profit organizations are encouraged to focus on generating commercial revenue from service delivery contracts.

b) Strengths of policies and operational processes in hybrid organizations in Indonesia, as follows: Law Number 25 of 1992 concerning Cooperatives, Law Number 20 of 2008 concerning Micro, Small and Medium Enterprises (MSMEs), and Law - Law Number 06 Year 2014 concerning Villages.

Research carried out on hybrid organizations (more broadly, for example: Cooperatives, MSMEs and BUMDesa) in the future should dedicate more efforts to explore the mechanisms by which new hybrid- organization companies achieve the benefits of innovation. A better understanding of this mechanism can help in building entrepreneurship theory. In addition, we know very little about how long a company must be able to absorb the costs of innovation before innovation really pays off. A better understanding of the time dimension can facilitate improved theories about the relationship of innovation performance and enlighten managers in small companies in new and more established hybrid organizations on how to effectively approach promising areas of innovation.

a) Research on hybrid organizations (broader, for example: Cooperatives, MSMEs and BUMDesa) in strategic management science is carried out using institutional, stakeholder and entrepreneurial approaches in the context of 8 schools of strategy management, so that they have optimization in strategy management.

b) How to build (or rebuild) a business model that clearly enables market leaders to block competition while triggering innovation in hybrid organizations in Indonesia.

\section{References}

[1] Chesbrough, H., 2010, Business model innovation: opportunities and barriers. Long. Range Plan. 43, 354e363. https://doi.org/10.1016/j.1rp.2009.07.010.

[2] Geissdoerfer, Martina; Savaget, Paulob; Evans, Steveb, 2017, The Cambridge Business Model Innovation Process; 14th Global Conference on Sustainable Manufacturing, GCSM 3-5 October 2016, Stellenbosch, South Africa Procedia Manufacturing 8 ( 2017 ) 262 - 269 The Cambridge Business Model Innovation Process.

[3] Geissdoerfer, Martin; Vladimirova, Doroteya; Evans, Steve., 2018, Sustainable business model innovation: A review.; / Journal of Cleaner Production 198 (2018) 401e416.

[4] Kompas.com., 2019 (Artikelinitelahtayangdidenganjudul"PrioritasInovasiKoperasiIndonesiaMendatang", http 
s://money.kompas.com/read/2019/12/09/124400626/prioritas-inovasi-koperasi-indonesiamendatang?page=all\#page2 (12 Desember 2019).

[5] Hansmann, H., 1980, The role of non-profit enterprise. Yale Law Journal, 89, pp. 835-901.

[6] Billis, D., 2010 Towards a theory of hibrid organizations. In Billis, D. (ed.), Hibrid Organizations and the ThirdSector. Basingstoke: Palgrave Macmillan, pp. 46-69.

[7] Dees, G. and Elias, J., 1998, The challenges of combining social and commercial enterprise. Business Ethics Quarterly, 8, pp. 165-178.

[8] Defourny, J. and Nyssens, M., 2010, Defining social enterprise. In Nyssens, M. (ed.), Social Enterprise at the Crossroads of Market, Public Policies and Civil Society. London: Routledge, pp. 1-28.

[9] Evers, A., 2005, Mixed welfare systems and hibrid organizations: changes in the governance and provision of social services. International Journal of Public Administration, 28, pp. 737 748.

[10] Liu, G. and Ko, W.-W., 2012, Organizational learning and marketing capability development: a study of the charity retailing operations of British social enterprise. Nonprofit and Voluntary Sector Quarterly, 41, pp. 580-608.

[11] Murphy, P.J. and Coombes, S.M., 2009, A model of social entrepreneurial discovery. Journal of Business Ethics, 87, pp. 325-336.

[12] Pache, A.C. and Santos, F., 2010, When worlds collide: the internal dynamics of organizational responses to conflicting institutional demands. Academy of Management Review, 35, pp. 455-476.

[13] Young, D.R., 2001, Organisational identity in non-profit organisations: strategic and structural implications. Nonprofit Management \& Leadership, 12, pp. 139-157.

[14] Santos, F.M., 2012, A positive theory of social entrepreneurship. Journal of Business Ethics, 111, pp. 335-351.

[15] Kerlin, J., 2010, A comparative analysis of the global emergence of social enterprise. Voluntas, 21, pp. 162-179.

[16] Austin, J., Stevenson, H. and Wei-Skillern, J., 2006, Social and commercial entrepreneurship: same, different or both? Entrepreneurship Theory and Practice, 30, pp. 1-22.

[17] Dees, J.G., 1998, Enterprising non-profits. Harvard Business Review, 76, pp. 55-67.

[18] Defourny, J. and Nyssens, M., 2010, Conceptions of social enterprise and social entrepreneurship in Europe and the United States: convergences and divergences. Journal of Social Entrepreneurship, 1, pp. 32-53.

[19] Borzaga, C. and Defourny, J. 2001, The Emergence of Social Enterprise. London: Routledge.

[20] Nyssens, M., 2006, Social Enterprise at the Crossroads of Market, Public Policies and Civil Society. London: Routledge.

[21] DTI., 2002, Social Enterprise: A Strategy for Success. London: Department of Trade and Industry.

[22] Laville, J.-L. and Nyssens, M., 2001, The social enterprise: towards a theoretical socioeconomic approach. In Borzaga, C. and Defourny, J. (eds), The Emergence of Social Enterprise. London: Routledge, pp. 312-332.

[23] Mair, J. and Martì, I., 2006, Social Entrepreneurship research: a source of explanation, prediction, and delight. Journal of World Business, 41, pp. 36-44.

[24] Peattie, K. and Morley, A., 2008 Eight paradoxes of the social enterprise research agenda. Social EnterpriseJournal, 4, pp. 91-107.

[25] Peredo, A.M. and McLean, M., 2006, Social entrepreneurship: a critical review of the concept. Journal of World Business, 41, pp. 56-65.

[26] Dart, R., 2004, The legitimacy of social enterprise. Nonprofit Management and Leadership, 14, pp. 411-424.

[27] Douglas, Heather; Eti-Tofinga, Buriata; Singh, Gurmeet., 2018, "Hibridorganisations contributing to wellbeing in Small Pacific Island Countries", Sustainability Accounting, Management and Policy Journal, https://doi.org/10.1108/SAMPJ-08-2017-0081

[28] Law Number 25 of 1992 concerning Cooperatives 
[29] Law Number 20 of 2008 concerning SMEs

[30] Law Number 6 of 2014 concerning Villages

[31] Borzaga, C. and Solari, L., 2001, Management challenges for social enterprises. In Borzaga, C. and Defourny, J. (eds), The Emergence of Social Enterprise. Basingstoke: Routledge, pp. 333349.

[32] Dees, G. and Elias, J., 1998, The challenges of combining social and commercial enterprise. Business Ethics Quarterly, 8, pp. 165-178.

[33] Billis, D. and Glennerster, H., 1998, "Human services and the voluntary sector: towards a theory of comparative advantage", Journal of Social Policy, Vol. 27 No. 1, pp. 79-98.

[34] Young, D.R. and Salamon, L.M., 2002, Commercialization and social ventures. In Salamon, L. (ed.), The State of Nonprofit America. Washington, DC: Brookings Institute Press, pp. 423446.

[35] Teasdale, S., Lyon, F. and Baldock, R., 2013, Playing with numbers: a methodological critique of the social enterprise growth myth. Journal of Social Entrepreneurship, 4, pp. 113-131.

[36] Eikenberry, A.M. and Kluver, J.D., 2004, The marketization of the non-profit sector: civil society at risk. Public Administration Review, 64, pp. 132-140.

[37] Mullins, D., Czischke, D. and van Bortel, G., 2012, Exploring the meaning of hibridity and social enterprise in housing organisations. Housing Studies, 27, pp. 405-417. 